\title{
THE APPROPRIATENESS OF CONCILIATION/MEDIATION FOR SEXUAL HARASSMENT COMPLAINTS IN NEW ZEALAND
}

\author{
Claire Baylis
}

In this article Claire Baylis examines the statutory models of mediation/conciliation in the Human Rights Act 1993 and the Employment Contracts Act 1991 which are used for sexual harassment complaints. She argues that the practice of mediating these complaints is inappropriate due to the incompatibility of the cha585he specific characteristics of most sexual harassment complaints. Further, an analysis of the actual dispute resolution provisions under the Acts raises other issues in the sexual harassment context. Finally the author outlines some possible reforms to dispute resolution processes in this area.

Grievance mediation of [sexual harassment] cases, no matter how well intended, risks trivializing the seriousness of sexual harassment and maintaining an inhospitable environment for the female workforce. ${ }^{1}$

\section{INTRODUCTION}

In a little over fifteen years, New Zealand has jumped on the mediation bandwagon. Interestingly, in contrast to the United States, the central thrust for mediation in this country has come as much from within the legal system as outside it. Mediation or conciliation processes have been incorporated by Parliament into some thirty statutes covering a wide range of subject areas, from resource management to family law, from the health area to employment including sexual harassment complaints. This enthusiasm for mediation processes has not abated, indeed it is spreading amongst the judiciary with a range of judicial comments to the effect that cases would have been more appropriately

Lecturer, Victoria University of Wellington. Deputy Director New Zealand Institute Of Dispute Resolution.

$1 \quad$ M Irvine "Mediation: Is it Appropriate for Sexual Harassment Grievances?" (1993) 9 Ohio State Journal On Dispute Resolution 27, 28. 
settled through mediation ${ }^{2}$, and with the recent High Court Review Committee's proposal to extend the use of mediation as a first step in civil hearings. ${ }^{3}$

Conciliation and mediation are the terms most frequently used in New Zealand statutes for processes by which a 'neutral' third party meets with the parties to a dispute, together or separately, to attempt to facilitate a settlement between them of some or all of the issues in dispute. In these processes, the neutral third party draws out each party's perceptions and interests, and attempts to find some common ground. Traditionally at least, the processes are voluntary and consensual, ${ }^{4}$ ideally producing a mutually beneficial settlement encompassing creative outcomes to the dispute. Mediation styles can be viewed as being on a spectrum from process-centred mediation which focuses on the parties reaching the decision themselves with more limited input from the mediator, to substance-based mediation where the mediator may evaluate the issues and make suggestions as to a resolution. ${ }^{5}$ The latter involves more of a focus on the parties' rights. However, there are a whole range of variables in mediation approaches which preclude any concrete distinctions being drawn. ${ }^{6}$

The style of mediation used and the distinction between mediation and conciliation largely depend on the individual mediator. The statutes in New Zealand tend to use the term conciliation in areas which may be seen as more relationship based such as antidiscrimination law and family law. Conciliation may also be seen to be focussed more on the remedy and future conduct rather than all aspects of the dispute. However, this is again dependant largely on the particular conciliator and on the way the parties approach the problem. While there are some claims of specific definitions for the two processes, there is often not a clear distinction in reality. ${ }^{7}$ In the context of this article, the general arguments

Maddever v Umawera School Board [1993] 2 NZLR 478,511 and Te Runanga o Wharekauri Rekohu Inc v Treaty of Waitangi Fisheries Commission and Ors Unreported, 27 November 1996, High Court, Wellington Registry CP 297/95, 7 .

See Courts Consultative Committee Court Referral to Alternative Dispute Resolution: Discussion Paper January 1997, 6-17 and Appendix One. ADR has also been promoted through the High Court Case Management Pilot Scheme in Auckland and Napier.

4 See for example J Rifkin "Mediation from a Feminist Perspective: Promise and Problems" (1984) 2 Law \& Inequality 21, 26; Submission of Arbitrators' and Mediators' Institute of NZ Inc May 1997 2 in Submissions to Courts Consultative Committee on Court Referral to Alternative Dispute Resolution June 1997.

5 See R Amadei \& L Lehrburger "The World of Mediation: A Spectrum of Styles" [1996] Oct Dispute Resolution Jnl.

6 For examples of these variables see National Working Party on Mediation Guidelines for Family Mediation: Developing Services in Aotearoa - New Zealand (Wellington, Butterworths, 1996) 13-15.

7 Different organisations/groups subscribe to different approaches on this issue. For example Howells and Cathro suggest that in the US the terms are used interchangeably and while in New Zealand different statutes etc use different terms, "both conciliators and mediators are 
relate to both processes, but the Human Rights Act 1993 ("the HRA") uses the term conciliation while the Employment Contracts Act 1991 ("the ECA") refers to mediation.

The mainstreaming of alternative processes such as mediation/ conciliation is to be applauded in many ways. It is a sign of a system eager to find 'new' and 'better' ways of dealing with disputes. ${ }^{8}$ It is evidence of a willingness to confront some of the problems with our court system. It may even be a recognition that there are some types of disputes which are not well suited to the adversarial system of justice. However, there is a risk of overenthusiasm, of a lack of reflection on these changes.

At this point in time, it is my conviction that New Zealand is in need of a questioning, a consideration of the point that we have currently reached in terms of ADR. Reflection must take place in terms of both the big picture and the detail. We need to consider the effects on the justice system as a whole and our changing conceptions of justice and process; ${ }^{9}$ but we also need to examine the specifics, how statutes establish mediation, the appropriateness of the process in the areas in which it is used and how in practice it is being used and to what effect.

This article, while raising some of the 'big picture' issues, and some of the practical efficacy details, focuses on the appropriateness of mediation/conciliation in the specific area of sexual harassment complaints. I believe that when the basic precepts of mediation/ conciliation are analysed in relation to the characteristics of sexual harassment disputes, there is a strong argument to suggest that mediation processes are inappropriate in this area and that compulsory conciliation should certainly not be used. Instead I will briefly outline

involved in mediation." JM Howells and SH Cathro Mediation in New Zealand: The Attitudes of the Mediated (Dunmore Press Ltd, Palmerston North, 1986) 20-21. More recently, the National Working Party on Mediation adopted a definition of mediation focussing on a process-centred approach, to distinguish it from other processes including conciliation. Above n 6, 5. The submission from LEADR to the Courts Consultative Committee defines conciliation as "occur[ing] in a statutory context where the conciliator who has duties imposed by statute adopts an advisory approach and may even make recommendations on settlement". LEADR June 1997 1, above $n$ 4. However, the only duty imposed on conciliators under the Human Rights Act is framed broadly as the duty "to use [their] best endeavours to secure a settlement between the parties on the matters in issue." Sections $80(2)(b)$ and $81(1)$ and (2).

8 Mediation processes are only new in the sense of inclusion into western legal systems, the processes have been used for centuries in other parts of the world, for example see L Nader Law in Culture and Society (Aldine Publishing Company, Chicago 1969) and R Antoun Arab Village (Indiana University Press, Bloomington 1972).

9 The Courts Consultative Committee Process is raising some of these issues in relation to the proposal of Court referrals to ADR. See for example the text accompanying footnote 34 below and above n 3, 21-27 and many of the submissions on the proposal for example the submissions of R Chapman, May 1997 and the Law Commission, May 1997, above n 4. 
a possible alternative drawing on the current investigatory approach used by the Human Rights Commission ("the HRC").

The argument that mediation/conciliation is inappropriate for the resolution of sexual harassment complaints is based on the thesis that in determining the type of dispute resolution process which should be used for a certain type of dispute, a central consideration should be an analysis of the match between the characteristics of the dispute and the nature, objectives and aims of the dispute resolution process itself. ${ }^{10} \mathrm{My}$ discussion on the topic is enhanced by a feminist perspective.

\section{THE USE OF MEDIATION IN SEXUAL HARASSMENT COMPLAINTS IN NEW ZEALAND}

In New Zealand, a woman ${ }^{11}$ who decides to take a formal complaint of sexual harassment in her employment can choose between proceeding under the HRA or under the ECA. ${ }^{12}$ If the harassment has taken place in one of the other areas covered by the HRA, which include access to goods and services, housing and education, she can proceed under that Act only.

The definitions in the two Acts are very similar. ${ }^{13}$ They basically cover two types of sexual harassment, one, the quid pro quo type, whereby an implied or explicit request for

10 For a more detailed discussion of this premise see $C$ Baylis "The Legitimacy of Environmental Mediation" LLM Thesis, VUW, 1992. See also C Menkel-Meadow "The Trouble with the Adversarial System in a Postmodern, Multi-cultural World" (1996) 38 William and Mary LR 5, 37.

11 While there are some sexual harassment complaints taken by men, I have explicitly gendered this discussion, because the problem is so commonly a male harasser, harassing a female. See $Z v$ $A$ [1993] 2 ERNZ 469, 472. In the context of the article it is imperative that systemic power imbalances between the genders are recognised and taken into account. For a report on a case involving a male complainant and female harasser see The Dominion, Wellington, New Zealand, 11 November 1997, 1. The case was presumably front page news because it involved a female harasser. Note also that where there is male victim, there is often still a male harasser, for example Proceedings Commissioner $v$ Peisi and Dyal CRT 8/96 cited in Human Rights Commission Annual Report 1996 as being the first successful case of male-to-male sexual harassment. For further examples of both these types of sexual harassment complaints see the Human Rights Commission Annual Report 1997. The US Supreme Court is to hear a case of male on male harassment, Oncale $v$ Sundowner, in December 1997 to determine whether this type of sexual harassment fits within the sex discrimination component of Title VII of the Civil Rights Act 1964. See Amicus curiae submissions written by Catherine Mackinnon at http://members.aol.com/map11215/oncale/ and article by J Stoltenberg "Male on Male Harassment" at http://www.feminista.com/v1n7/ stoltenberg.html.

12 Although there are also other relevant and intersecting statutes which cover specific organisations/institutions; see for example section 91 and the Fifth Schedule of the Police Act 1958.

Section 62 of the Human Rights Act 1993 and section 29 of the Employment Contracts Act 1991. 
sexual activity is made with the implied or explicit promise or threat that preferential or detrimental treatment will result. Secondly, the definitions cover the hostile environment type of sexual harassment whereby language, visual material or physical behaviour of a sexual nature occurs which is unwelcome or offensive to the person and is repeated or so significant as to have a detrimental effect on that person.

For the purposes of this article I will focus only briefly on the specifics of each of the legislative processes. Under the ECA, the Employment Tribunal has a broad mandate for providing mediation assistance as it can do so whether or not a dispute fits within its jurisdiction. ${ }^{14}$ When a matter is within the Tribunal's jurisdiction, the parties can apply formally for mediation, ${ }^{15}$ or they can approach the Tribunal informally. ${ }^{16}$ Alternatively parties may end up in mediation by applying to the Tribunal under its adjudication function at which time one of the Tribunal officers will determine whether mediation should be attempted prior to adjudication. ${ }^{17}$ In practice, according to Anderson and Thompson, if one party is unwilling to attempt mediation, they will not be required to do so. ${ }^{18}$

Section 88(2) of the ECA contains one of the most problematic features of mediation under the Act. Section 88 purports to discuss procedure, but subsection (2) states that where mediation assistance is provided under the adjudication jurisdiction of the Tribunal,

... and as a result the parties conclude a settlement or agree to the [Tribunal] member making

a decision, the parties may request the member to sign the terms of settlement and in any

such case those terms of settlement shall be final and binding on the parties.

First, this provision allows the parties to authorise the Tribunal member to decide the outcome of their dispute or any part of it. Thus the consensual nature of mediation is changed in this circumstance into a hybrid of mediation and arbitration. Secondly, what makes this all the more problematic is that this decision becomes final and binding on the parties.

Practically this hybrid procedure has been used in a considerable number of cases ${ }^{19}$ and was subject to a number of judicial determinations, culminating in Shaffer $v$ Gisborne High School Board of Trustees where the Court of Appeal held that the words should be given

Section 78(2), (3) and (4) of the ECA 1991.

Section 78(3) of the ECA 1991.

Section 78(4)(b) of the ECA 1991.

Section 80(2) of the ECA 1991.

G Anderson, M Thompson (eds) Mazengarb's Employment Law (Butterworths, Wellington, 1993) A1664, para 80.2.

Above n 18, A1679 para 88.3. 
their plain meaning. ${ }^{20}$ Thus the Court held that decision-making power could be conferred on the mediator and that such a decision could not be appealed to the Employment Court, although it could be the subject of an application for review.

The vast majority of sexual harassment cases in New Zealand however, are taken through the HRC process rather than under the ECA. ${ }^{21}$ Once a complaint is received by the HRC, the Complaints Division decide whether to investigate or to attempt informal settlement. ${ }^{22}$ If they do investigate, they will speak to the complainant, the alleged harasser and any other relevant people, and finally reach an opinion as to whether the complaint has substance. The Complaints Division has, as one of its general functions, to act as a conciliator in relation to any complaint. ${ }^{23}$ There are two possible uses of this conciliation function under the Act, both of which can apply to sexual harassment complaints. First, conciliation may be used upon receiving a complaint or during the Commission's investigation into a complaint, if the investigating officer thinks that it may be possible to reach a settlement between the parties, and it is this process which is generally preferred by the Commission. ${ }^{24}$ Secondly, the Act states that conciliation shall be used when a complaint has been investigated and the Complaints Division are of the opinion that it has substance. ${ }^{25}$ The mediator may be an investigating officer, a mediator from the Commission or if compulsory mediation is used, a Commissioner. The conciliation may be carried out by either shuttle or face to face conciliation.

In deciding to write on the appropriateness of conciliation/mediation for sexual harassment complaints, I am aware that my argument may give rise to a number of dangers which I wish to counter explicitly. First, I am conscious that to be criticising the processes established by the ECA and the HRA at this time may lend ammunition to those in Parliament and society who do not support the institutions set up by the two Acts. I am not advocating the abolition of either the specialist Employment Court or the Human Rights Commission. I view it as imperative that women have the choice of procedure. I also maintain that in general terms women are more likely to get justice in these institutions than from the general court system due to the greater education of the key players on the nature of sexual harassment.

[1995] 1 ERNZ 94.

See text below accompanying footnote 88 .

Sections 75 and 76 HRA 1993.

Section 75(c) of the HRA 1993. It also has the same function in relation to investigations of its own motion under section 75(f).

Human Rights Commission Annual Report 1997. Section 81(1) of the HRA 1993.

Section 81(2) and for investigations of its own motion, section 81(3) of the HRA 1993. 
Secondly, I am reluctant to criticise the HRC's work in the area of sexual harassment as I know that many women have relied on the Commission and that the Commission's work has made a huge impact in the anti-discrimination field. However, I believe that open debate on potential problems can lead to positive change if views are taken in the vein they are intended.

Finally, when I gave an overview of this paper as a seminar in the UK last year, a number of academics, while agreeing with some of the disadvantages of mediation, argued vehemently against a return to an adversarial process for these complaints, based on their own experiences in that country. ${ }^{26}$ As I have already indicated, I too, am not advocating an adversarial procedure for sexual harassment complaints, but rather I will outline a possible alternative based on the investigatory approach of the HRC.

\section{ANALYSING THE APPROPRIATENESS OF MEDIATION FOR SEXUAL HARASSMENT CASES IN NEW ZEALAND}

Mediation/conciliation is often viewed by its proponents as a "better" process of dispute resolution than the Court system, or at least a better starting point in achieving a resolution. It is also thought by many to achieve "better" results than the adversarial process. Both the claims of a better process and a better outcome can and have been questioned generally, but they can also be analysed specifically in the context of sexual harassment complaints.

\section{A Mediation: A "Better" Process}

As mediation has become a recognised alternative to the court system, inevitably much of its legitimacy has arisen from comparing it to the adversarial system and focussing on the advantages that mediation has over that system. Mediation has been touted as cheaper and faster than the Court process. ${ }^{27}$ It is seen by many as a process which empowers the parties, giving them a real say in the outcome of their dispute. ${ }^{28}$ This empowerment has been seen by some as being of particular importance for women and minority groups. ${ }^{29}$

Proponents of mediation argue that due to its informal nature, it focuses on the parties' perceptions and accounts of the facts, and has the ability to draw out the common interests

The seminar was given at the University of Newcastle Upon Tyne Law School, May 1996.

27 For example above n 18, A1667, para 80.2; see also discussion in H Astor and CM Chinkin Dispute Resolution in Australia (Butterworths, Sydney 1992) 14.

28 For example, J Folberg and A Taylor Mediation - A Comprehensive Guide to Resolving Conflicts Without Litigation (1ed, Jossey-Bass Inc Publishers, California, 1984), 10; and National Working Party on Mediation, above n6, 4. 
and goals of the parties. This informality also allows other normative systems to be considered as well as merely the law, which can allow the process to be more culturally sensitive to Maori and other groups whose cultural norms fall outside the Anglo-centric legal system. ${ }^{30}$ Some feminist commentators view this as advantageous to women, in the belief that women generally approach problems in a different way to the traditional male decision-makers who have monopolised the legal system. ${ }^{31}$ This view purports that women are more likely to take into account the broader context of the dispute and the interconnecting themes and relationships which are involved. ${ }^{32}$

Mediation is often viewed as being better able to deal with certain types of disputes which the courts may struggle with: disputes which involve on-going relationships; have many parties; or which are polycentric in that they have many interwoven issues.

Finally the private and confidential nature of mediation is also seen as beneficial, allowing the parties to open up fully to one another without risk of prejudicing themselves in any later proceedings, should settlement not be achieved. It also ensures that any settlement that is reached is based upon a full and frank disclosure of the parties' interests and perceptions. The protection of the parties' privacy may also help to increase the chances that a settlement will be achieved.

Many of these claims when examined in relation to sexual harassment complaints specifically can be found to be dubious, irrelevant or in fact damaging.

\section{Cost Efficiency Claims}

As mediation began to develop in western countries as an alternative to the Court System, its proponents claimed that it would provide better access to justice because of its cost efficiency compared to the adversarial system. With the 'second wave' of thinking on ADR there was more of a critical analysis of these claims. ${ }^{33}$ Nevertheless, there is still a general claim that mediation is quicker and cheaper than the Court process. Indeed one of

30 For example see Courts Consultative Committee, above n 3, 6 .

31 See for example C Gilligan and C Menkel-Meadow in DuBois et al "Feminist Discourse, Moral Values and the Law - A Conversation" (1985) 34 Buffalo Law Review 11, 36-66; C Gilligan In a Different Voice: Psychological Theory and Women's Development (Harvard University Press, Cambridge, Mass, 1993); C Menkel-Meadow "Portia in a Different Voice: Speculations on a Women's Lawyering Process" (1985) 12 Berkeley Women's LJ 39, 52-53; Justice B Wilson "Will Women Judges Really Make a Difference?" (1990) 28 Osgoode Hall Law Jnl 507, 519-522. For a critique of this view see T Grillo "The Mediation Alternative: Process Dangers for Women" (1991) 100 Yale Law Jnl 1545, 1601-1605.

32 Above $\mathrm{n} 31$

33 E Brunet "Questioning the Quality of Alternative Dispute Resolution" (1987) 62 Tulane LR 1, 4-6. 
the principal objectives of the High Court Review Committee proposal for introducing courtordered mediation is the possibility of reducing costs and delays in civil cases, saving judicial time: ${ }^{34}$

Judicial time is a scarce and expensive resource. We consider that no one should be entitled to the use of Court hearing time unless and until other reasonable means of resolving the dispute have been attempted. Although such means will sometimes fail, the time involved is not wasted if the issues have been better defined or in part resolved.

The HRC has a similar view: "[i]n order to increase the timeliness and effectiveness of its service, the Complaints Division continues to emphasise the benefits of conciliating complaints, as opposed to investigating and then obtaining a formal finding or Complaints Division opinion." ${ }^{35}$

The law and economics movement too, has focussed on the efficiency benefits of private ordering, which apply to a large extent whether the settlement process is under state control or not. Settlement processes are seen as allowing more 'flexibility', and giving the parties more individual freedom thus producing more economically efficient outcomes. "It is suggested that contracting parties generally act 'rationally', in the sense that they make agreements under which the benefits they receive outweigh the costs" and because these are made on an individual basis the cost-benefit decisions are more likely to be accurate ${ }^{36}$ Such an analysis may be found to be wanting from both a theoretical and a practical viewpoint.

Practically, some mediation processes may be more cost efficient than the court system. However, this is not a universal truth. Indeed some mediators have themselves pointed out that such claims can be misleading and can compromise the effectiveness of the process. The Courts Consultative Committee discussion paper also points to problems with such a claim: "[i]n any analysis of costs and benefits the question of whether change leads to a net benefit overall has to be considered...[which would include] an investigation of whether there may be a loss of efficiency overall with costs... exceeding the benefits. ${ }^{.37}$ Indeed a recent five-year study in the US of a programme which introduced mediation and mandatory arbitration into ten federal District Courts in California found that these processes "yielded no significant

34 Above n 3,11.

35 Human Rights Commission Annual Report 1996, 29.

36 M Neave "Private Ordering in Family Law - Will Women Benefit?" in M Thornton (ed) Public and Private: Feminist Legal Debates (OUP, Melbourne, 1995) 144, 165.

37 Above n 3, 12. This point was discussed further in a number of the submissions on the paper, for example from the Ministry of Justice 30 May 1997, 5 in above $n 4$. 
decrease in litigation costs, resolution time or attorney satisfaction." ${ }^{38}$ If mediation is successful the process may be more cost-effective but if it is not, another layer of procedure is added which adds to both the costs and the time taken.

Not only are the cost efficiency claims difficult to assess, but in addition, they cannot be taken out of the particular context in which the settlement process takes place. As Neave points out, the fact that women are negotiating in the employment and family law context, and in sexual harassment disputes generally, from a position of pervasive gender inequality "constrains their ability to make agreements that benefit them." ${ }^{.39}$ Neave illustrates her point in the employment area, "[w]omen negotiating with employers continue to earn significantly less than men, despite acceptance of equal pay principles and the enactment of equal opportunity legislation. ${ }^{40}$ The example is equally persuasive in the New Zealand context. ${ }^{41}$

Further, there is the more fundamental question of the degree to which cost-efficiency should be viewed as a central factor in determining which dispute resolution process to use in a specific area. From a law and economics' perspective such a question may well be unpopular, although many economists accept that economic efficiency is but one factor in the equation rather than the central determinant. ${ }^{42}$ There is no doubt that too much of an emphasis can be placed on cost-efficiency in terms of dispute resolution processes, especially those which purport to be part of the justice system. The chances of a settlement being fair, creative and mutually beneficial will be reduced if a mediator or the parties are attempting to rush through the process without having any understanding of their legal rights. The aim of any dispute resolution process established by law is not merely the speedy or inexpensive disposition of cases, ${ }^{43}$

... but to dispense justice. Dispensing justice does not carry with it the same unspoken implications of speed for the sake of speed. Rather, it embodies a concept of timeliness but recognises that it is secondary to the overall achievement of justice.

S Goldberg "Rand-ly Criticized" [1997] ABA Jnl 14 - reporting on the findings of the Rand Institute for Civil Justice in Santa Monica, California Just, Speedy and Inexpensive? An Evaluation of Judicial Case Management Under the Civil Justice Reform Act.

39 Above $\mathrm{n} 36,168$.

40 Above n 36, 144, 167 referring to Australian Bureau of Statistics, Women in Australia, Cat. no 4113.0, ABS, Canberra 1993, 179.

41 See for example J Morris "Women's Access to Justice: He Putanga Mo Nga Wahine Ki Te Tika Justice is Not Blind to the Effects of Gender" (1996 New Zealand Law Society Conference Papers) 9, 11-12.

42 See Law Commission Submission, June 1997, above n 4, 6-7.

43 Canadian Task Force on Systems of Civil Justice Report of the Canadian Bar Association August 1996, 14. 
While timeliness and expense are obviously connected with justice, they do not of themselves lead to it. Thus they may be a factor in a determining the type of dispute resolution process which should be used, but cost efficiency does not obviate the need to analyse the appropriateness of a specific type of dispute resolution mechanism in relation to the type of dispute to be resolved.

To the extent that cost-efficiency to the state has influenced the use of mediation by the legislature, it is interesting from a feminist perspective to consider the degree to which this has occurred in the 'soft' law areas. These areas tend to be associated with the private sphere of society and with women and minorities, such as health, family, and antidiscrimination law. State resources appear to be more readily available for the areas of law more commonly associated with the public market place, the traditionally male arena, such as banking, commercial and company law. Resources are also available for other 'serious' public areas of law such as the criminal law.

The legislated use of mediation/conciliation in the sexual harassment area may partly be a reflection that these complaints are not viewed as 'seriously' by law and policymakers, and are therefore not worthy of a large allocation of resources. ${ }^{44}$ Indeed, a lack of resources for the Human Rights Commission means that a woman making a complaint of sexual harassment may face a considerable delay before her complaint is processed. ${ }^{45}$ The argument is again strengthened when the other possible justifications for using mediation/conciliation are analysed and found to be lacking in persuasiveness in this context.

In fact, the proposed process which I will briefly outline in the last section of this paper may be more cost-efficient than the present HRA process.

\section{Empowerment in Situations of Power Imbalance}

Mediation/conciliation can be an empowering process which gives the parties a direct input into the outcome of their dispute, in contrast to the adversarial system in which a 'distanced' third party imposes a decision. Yet a compromise-oriented settlement process, even if it is facilitated, is not universally appropriate to all types of dispute. Particularly, it may not be appropriate to those disputes in which there is a significant power differential between the parties, as has been recognised by many commentators. In this situation

44 For a discussion on informal justice as a political choice reinforcing dominant structures and providing a second-class system of justice to those who are disempowered in society see $R$ Abel The Politics of Informal Justice : Volume One: The American Experience (Academic Press Inc, New York, 1982).

45 The complaint is likely to be taken as soon as possible, but the investigation is unlikely to occur immediately. Above n 24, 21. 
empowerment is likely to become a one-sided phenomenon, leaving the complainant potentially dissatisfied, manipulated and vulnerable.

Sexual harassment usually occurs in situations in which there is a power differential. It may be that this differential is overt, for example where the harasser is the woman's employer, lecturer or teacher, or where the woman is one of the only female employees, is new to the job, or is in her first job. However, even if the sexual harassment occurs between apparently equal co-workers or between students, there is still a systemic power imbalance in most cases. Predominantly this is a gender power imbalance which explains the overwhelming incidence of men sexually harassing women; but heterosexism and racism can also be fundamental to a systemic imbalance in power.

Sexual harassment is about power and inequality. ${ }^{46}$ For a man to sexualise the workplace, for him to make inappropriate sexual suggestions or to push his sexual behaviour upon a woman is an attempt to objectify and disempower her. "[I]t is a sexual invasion, an act of sexual aggression, a violation of sexual boundaries...." ${ }^{47}$. Even if a woman does not 'rationally' think that this man would force sex on her, rape her, there is the possibility, the fear of that. To force someone to do something, or be subjected to behaviour which they do not consent to, is a form of dominance, it is about disempowering the other person, about empowering yourself. In the context of sexual harassment it is about male dominance: "[w]ere there no such thing as male supremacy and were it not sexualized, there would be no such injury as sexual harassment."48

The impact of this power differential in a mediation/conciliation, can be intensified if the woman employee who complains is less skilled, and/or after the trauma of sexual harassment less able, to advocate effectively for herself, than the male harasser, especially if a face to face mediation technique is used. ${ }^{49}$

46 See for example, J Morgan "Sexual Harassment and the Public/Private Dichotomy: Equality Morality and Manners." in M Thornton Public and Private: Feminist Legal Debates (OUP, Melbourne, 1995) 89 - 110. This inequality focus is reflected in the fact that sexual harassment has been recognised by the Courts and the Legislature in New Zealand and overseas as being a form of sex discrimination. For example, in New Zealand the Equal Opportunities Tribunal recognised sexual harassment as a form of sex discrimination under the Human Rights Commission Act 1977 in $H v E$ [1985] 5 NZAR 333; and one of the headings in the Human Rights Act 1993 refers to sexual harassment as one of a number of "other forms of discrimination".

47 C MacKinnon Only Words (Harper Collins Publishers, London, 1995) 40.

48 Above $n$ 47, 41.

49 For parallel comments made in the domestic abuse areas see D Stallone "Decriminalization of Violence in the Home: Mediation in Wife Battering Cases" (1984) 2 Law \& Inequality 493, 510. 
In addition, the woman may be more averse to using litigation because of the "psychologically debilitating court procedures" ${ }^{150}$. While it may be argued that the alleged harasser has potentially more to lose than the complainant if the case goes to litigation, the Court System as a whole does not have a tradition of protecting women's rights and understanding specifically gender harms, whether for sexual assault, domestic violence or sexual harassment. In fact its reputation is of 're-assaulting' women in these areas. The negative impact of the adversarial system on the complainant in sexual harassment cases is analogous to its impact in sexual assault cases which has been widely analysed academically ${ }^{51}$ and was recognised by a New Zealand Judge in 1996 when he stated that it was his view that "it would only be in the most extreme circumstances that you would ever advise a woman to participate in the criminal process if she was alleging that she had been raped." 52 Thus the complainant in a sexual harassment case may be very reluctant to go through the court process. This significantly increases what she has at stake in the mediation and can make her more inclined to accept an unfavourable or less favourable settlement. ${ }^{53}$

Once the inherent power imbalance between the complainant and the harasser is recognised, one of the key reasons why mediation/conciliation is inappropriate in sexual harassment cases is identified. Much of the analysis of mediation processes suggests that mediation is not able to deal effectively with cases which involve a significant power differential. Perhaps the most commonly identified type of dispute where this issue has been raised is in the family law context, ${ }^{54}$ particularly in situations where women have been physically and/or psychologically abused by their partners. ${ }^{55}$ Much of the discussion relating to those types of situations is also applicable to sexual harassment complaints.

Stallone recognises that in the domestic abuse context mediation cannot address "the conditions that institutionalise abuse, such as a woman's isolation in the family, her economic dependence on her husband, and the social system that reinforces the husband's

50 B Garth "The Movement Towards Procedural Informalism in North America and Western Europe: A Critical Survey" in R Abel (ed) The Politics of Informal Justice: Volume Two: Comparative Studies (Academic Press Inc, New York, 1982) 183, 200.

51 For example, see the papers in J Broadmore, C Shand and T Warburton (eds) The Proceedings of Rape: Ten Year' Progress? An Inter-Disciplinary Conference (DSAC, Wellington, 1996) 48-132.

52 Justice Ellis "The Rape Trial: Are the Scales of Justice Evenly Balanced?" Panel Discussion, above n 51, 82.

For a discussion of this concept in the divorce context see RH Mnookin and L Kornhauser "Bargaining in the Shadow of the Law: The Case of Divorce." (1979) 88 Yale LJ 950.

54 For a general analysis, see above n 36. 
Even if a mediator is trained in the aetiology/pathology of sexual harassment, which may be more likely under the HRA than the Employment Tribunal process, this does not eliminate the prejudicial attitudes of the harasser having some effect on the outcome, especially when the mediator does not have formal procedural or evidential rules to draw on.

In situations where the mediator is well trained in gender issues and the nature of sexual harassment, the mediator is placed in an incredibly difficult position if they attempt to rectify the power imbalance, educate the alleged harasser about sexual harassment or circumvent the alleged harasser's views on a particular point. The mediator is meant to act neutrally, and while feminist, race and critical legal analysis has debunked the myth of objective neutral players in our justice system, overt behaviour which appears to favour one party in a mediation is still likely to raise objections from the other party.

Some readers may wonder at this point if my argument is not contradictory. On the one hand I suggest that formal court procedures can be so traumatic and debilitating that women may agree to an adverse settlement merely to avoid such a process, while on the other I argue that mediation lacks formal processes which provide protections in situations of power imbalance. To a degree such a criticism is fair and merely reflects the complexities of the situation and the reality that no dispute resolution process will be a panacea for all problems. However, the criticism also rests on an assumption, the assumption that I am choosing between the dichotomous processes of the adversarial system as opposed to mediation.

This assumption is backed by Rifkin, who argues that the type of objections to mediation which focus on the lack of procedural checks due to its informality are "inextricably tied to the view that the formal legal system offers both a better alternative and a greater possibility of achieving a fair and just resolution of the conflict." ${ }^{66}$ I agree that this is the approach of some commentators who make these criticisms. ${ }^{67}$ Rifkin challenges this view, arguing for example, that legal advocacy too can reinforce patterns of dominance due to the active lawyer and passive client relationship, especially when the client is female. ${ }^{68}$ However, I am not intending to frame the problem in terms of a dichotomy. I do think that it is essential to recognise and discuss the problems that exist in both the adversarial process and in mediation. I also think we need to break out of these particular categories of dispute resolution and examine alternatives. ${ }^{69}$ In the specific area of sexual harassment I will

J Rifkin above $n 4,30$

67 For example above $\mathrm{n} 60,1403$ and 1404.

J Rifkin above n 4, 30 . 
suggest that an investigatory process should be examined as a serious alternative in the area.

In New Zealand we recognise the detrimental effect of power imbalances in family law cases which involve domestic abuse, and consequently we have, for example, determined that protected people under the Domestic Violence Act 1995 cannot be required to attend joint programme sessions at which the violent party is present. ${ }^{70}$ It is essential that the same considerations are applied in the sexual harassment area where after all complaints can and do involve serious sexual assaults as apparently with the case described above. To allow the mediation of sexual harassment complaints will often be far from an empowering process for the woman complainant.

\section{Compulsion and the Pressure to Settle}

The potential for problems due to the power imbalances inherent in sexual harassment cases are heightened by some of the specific features of conciliation under the Human Rights Act 1993 and mediation under the Employment Contracts Act 1991.

Under the Human Rights Act there are two uses of conciliation. First, the Complaints Division may decide to use conciliation on receipt of a complaint or during an investigation into a complaint. The power to do this lies in section 81(1) of the Act, and while the Commission acknowledges that "sexual harassment complaints are particularly difficult to conciliate early because of the high levels of emotion involved. Commission staff have nevertheless continued to increase the numbers of sexual harassment complaints being settled early"71. While this power may appear to involve voluntary conciliation this is not necessarily the case. It is the Complaints Division which has the discretion to decide whether to conciliate; once the decision is made it can then call a conciliation conference to identify the matters in issue and to attempt settlement of those matters. ${ }^{72}$ Should one party fail to comply with a request to attend such a conference "the Proceedings Commissioner may issue a summons requiring the person to attend a conference at a time and place specified. ${ }^{173}$ Thus even this use of conciliation may involve the parties being compelled to attend a conciliation conference against their wishes.

Section 31 of the Domestic Violence Act 1995.

Above $n$ 24, 21. In the 1996 reporting period, 12 of the 52 sexual harassment complaints considered were settled without an investigation, while this rose to 14 of the 48 considered in the 1997 reporting period.

Section 80(1) and (2) of the Human Rights Act 1993.

Section 80(3) of the Human Rights Act 1993. Such a summons is to be treated as equivalent to a Witness Summons under the Summary Proceedings Act 1957. 
The second use of conciliation under the Human Rights Act 1993 is compulsory conciliation which takes place once an investigation is complete and the Complaints Division has formed the opinion that the complaint has substance. ${ }^{74}$ While the parties can again be forced to conciliate, what is even more disturbing here is that on the words of the provision, the Complaints Division itself has no discretion to choose not to conciliate, as the provision is framed in terms of a duty to conciliate at that point. Thus under the HRA the ethos of mediation as being a consensual and voluntary process is overridden.

The motivations for compulsion are varied. They may be linked to the cost-efficiency claims of the process, as well as the better outcomes type of claim. They may also stem from a belief that "the best way to educate [parties] about the benefits of mediation, as well as the best way to prevent one [party] from immediately forcing...litigation by refusing to mediate, [is] to mandate mediation prior to any court hearing...." ${ }^{75}$. These types of motivations go hand in hand with the belief that if mediation is attempted and fails, nothing is lost: "If the parties are unable to resolve their dispute in mediation, the mediation results remain confidential and the judicial process continues. ${ }^{176}$ Again there are two levels of criticism of the compulsion element. First, the general criticisms and secondly those that arise because of the nature of sexual harassment cases.

Mandatory mediation is a controversial topic among both commentators and practitioners in the area. Most of the submissions to the Courts Consultative Committee on the High Court Review Committee proposal focussed on compulsion as being a, if not the, key issue in the proposal, and the majority of the submissions rejected a compulsory system. ${ }^{77}$ The main practical reasons for the rejection were the need for mediation to be a voluntary process if parties were to feel empowered ${ }^{78}$ and if it was to be effective, ${ }^{79}$ especially due to the lack of available trained mediators. There was also a recognition of the increased possibility of abuse in mandatory mediation by unprincipled parties or by

74

Section 81(2) of the Human Rights Act 1993.

J Rosenberg "In Defense of Mediation" (1991) 33 Arizona Law Review 467, 472.

Above n 75, 472, footnote omitted. The High Court Review Committee has articulated a similar view, see text accompanying footnote 34 .

See for example the submissions from Ministry of Justice, 1; the Legal Services Board, 3; NZ Law Society, 8; Wellington South Community Law Centre para 6.1, in above $\mathbf{n} 4$.

7 For example, see the submissions from the Arbitrators' and Mediators' Institute of New Zealand, 2; the Law Commission, 7; the Legal Services Board, 4; and the NZ Law Society, 4 and 8 in above n 4 .

For example see the submissions from the Ministry of Justice, 3; the Ministry of Commerce, 3; the New Zealand Law Society, 4 and 8, in above $n 4$. 
counsel. ${ }^{80}$ On a policy level, the central concern was that access to the court system is a fundamental right to citizens which must be assured. ${ }^{81}$

These concerns were raised by key players in the legal system and in mediation, all of whom are knowledgeable and have expertise in the area. All the concerns are all the more pertinent to the conciliation of sexual harassment (and discrimination generally), yet they did not deter the legislature from adopting a compulsory model of conciliation under the HRA in 1993. In sexual harassment cases the potential for manipulation by one party is obviously a fundamental issue, as manipulative behaviour has already occurred if the complaint is genuine. The effectiveness of the conciliation process is already in doubt due to the power imbalances inherent in these situations, and thus the need for trained mediators, educated in the gender specifics of sexual harassment is all the more imperative.

When a woman has taken a sexual harassment complaint, she may strongly object to having to conciliate and for good reason. The effects of the behaviour on her can be highly destructive and traumatic. Protecting the complainant from further mental anguish should be a paramount consideration especially once the Complaints Division agree that her complaint has substance. Conciliating at that stage, does not give a clear message that under the HRA sexual harassment is inappropriate and illegal behaviour. When the complaint has been found to have substance and the parties are then told they have to conciliate, the message that is given to the complainant is that we agree with your version of the events (in part at least) but we will now give the harasser a stake in determining his punishment. This gives the harasser much more power than would ever be the case in even a minor criminal charge. The public and law-makers themselves would be most unwilling to allow someone charged with sexual assault to have a real input into the determination of their sentence, yet the behaviour complained of in the sexual harassment case could be exactly the same behaviour. As Irvine recognises, sexual harassment is a type of case "better suited for a mechanism that involves fact-finding and decision making" because "ultimately, we need to draw bright lines delineating acceptable behaviour in the workplace." ${ }^{112}$

There are also fundamental problems with the view that the parties do not lose anything by compulsorily making them conciliate. Proponents of mandatory conciliation may argue that the compulsion is merely to get the parties to the table. They can still decide not to settle and can go on to an adversarial setting such as the Complaints Review Tribunal. Astor and

For example see the submission from Roger Chapman, 9 in above $\mathbf{n} 4$.

81 For example see the submission from the New Zealand Law Society p9, in above $\mathbf{n} 4$.

82

Above n 1, 28.
} 
Chinkin debunk this myth in the Australian context of workplace discrimination on the ground of gender, and their comments are even more pertinent to sexual harassment claims: ${ }^{83}$

A woman working for a large organisation who suffers ... discrimination will probably be referred first to a workplace grievance procedure. If this fails she may complain under federal or State anti-discrimination legislation under which she will be referred to a statutory conciliation scheme. If the dispute is not resolved there may be reference to a specialist tribunal. A great deal of emotional reliance is required to proceed to an enforceable determination and the likelihood is high that the dispute will not be resolved, but will be avoided by the woman changing jobs or deciding to 'lump' the problem. The complaint is unlikely to result in any beneficial elaboration of the sometimes problematic statutory provisions dealing with workplace discrimination nor any structural reform with real consequences for the removal of discrimination. Nevertheless the appearance is presented that both the employer and the state are progressive and are committed to the elimination of discrimination against women.

At the HRC the vast majority of complaints do settle at conciliation, and this in itself can foster an environment where there is an expectation of settlement. For example in the 1995 reporting period there were 40 official complaints of sexual harassment opened, in 1996 there were 55 and in 1997 there were $52 .{ }^{84}$ During the 1996 reporting period only five cases involving sexual harassment were taken to the Complaints Review Tribunal by the Proceedings Commissioner, while in 1997 seven cases were taken. Although some complaints may have been dropped or found not to have substance, the settlement rate is obviously high. This is viewed by some people involved in the area as showing the degree of success of the procedures and the satisfaction of the parties. However there has been no research on how the parties felt immediately after settlement and a few months later.

The danger is that a high settlement rate leads to an expectation by mediators that settlement is appropriate and will be reached, which may in turn lead to pressure on the parties to settle. For a party to refuse to settle may be very difficult and involve holding out, yet: ${ }^{85}$

... [t]o the extent that disputants perceive themselves as having to agree, the mediator has overstepped the boundaries between mediation and the imposed decision-making of arbitration. This violates the core values of mediation, including autonomy, fairness and informed consent...

Above n 27, 15.

In 1996 and 1997 sexual harassment was the most significant ground of complaint, making up over 19\% of complaints in 1996 and $28 \%$ in 1997 . Above $n$ 35, 28-29 and n24, 21 and 33.

Above $n$ 6, 16. 
Conceivably refusing to settle may prejudice the party as it is the Proceedings Commissioner who decides whether to instigate proceedings in the Complaints Review Tribunal. A refusal to settle when this was the expected result could make the Proceedings Commissioner less likely to file proceedings due to a lack of co-operative behaviour on the complainant's part. While the complainant can take proceedings if the Commissioner declines to, any cost award will then be made against the complainant rather than the Commission.

The pressure to settle in sexual harassment cases may be higher than in other discrimination cases due to the intensely personal nature of sexual behaviour. The complainant will already have discussed the facts in detail for the Investigating Officer, and again possibly at the mediation. To then go through the facts a third time in an adversarial setting may well prove too daunting for many complainants.

Even if parties are explicitly informed that they do not have to settle at conciliation, that there is the Complaints Review Tribunal to hear the case, the shocking delays that have until recently taken place at that level would put many parties off, and may even have led Complaints Officers to warn parties against the option of not settling. ${ }^{86}$ There are also the difficulties identified by Astor and Chinkin referred to above that again reduce the real choices that complainants have in deciding not to settle at conciliation. ${ }^{87}$

This suggestion that the choice not to settle may often be more theoretical than real is also relevant to the specific problems which arise due to the nature of the Employment Contracts Act process. Far fewer cases are heard under the ECA process than under the HRA. "In the five years since the passing of the ECA, sexual harassment cases before the Court and the Tribunal have rarely numbered more than 10 , and in the first three years no more than two cases per year were heard." ${ }^{18}$

86 In mid-1995 a new Chair was appointed to the Complaints Review Tribunal to allow the existing Chair to clear the backlog of judgments on cases which had already been heard. By mid-1996 five of the outstanding decisions had been delayed for up to 2 years. Due to the lack of success by the Proceedings Commissioner to make the Chair hand down the decisions, the Proceedings Commissioner commenced judicial review proceedings in the High Court, which finally prompted the Chair to produce the judgments. While the case load has been handled far more efficiently since the change in Chair, the effects of these delays on the reputation of the Tribunal will continue for some time. Above $n$ 35, 37. There is now no backlog in the Tribunal and decisions are usually handed down within one to two months of the hearing. Above n 24, 33.

87 See text accompanying footnote 83.

88 C Morris "Sexual Harassment in New Zealand" Unpublished paper, Victoria University of Wellington, 1996, 5. Parts of this research are published in C Morris "An Investigation into Gender Bias in the Employment Institutions" (1996) 26 NZ Jnl Ind Rel 67. 
Section 88(2) of the ECA by sanctioning the hybrid process of med-arb, raises a range of general issues at both the pragmatic and philosophical levels. ${ }^{89}$ The hybrid process is again of particular concern when it is used for sexual harassment complaints. Even though the parties agree to its use they may not fully comprehend the dangers involved in the process, particularly the degree of pressure to reach a settlement that can result from the ability of the med-arbiter to impose a decision so that "what appears to be a negotiated resolution may be perceived by the parties as an imposed one, thus diminishing the degree of satisfaction and commitment." ${ }^{190}$ As White points out, even when a mediator does not have the arbiter function as well, $s$ / he does have a large degree of influence and may "suggest solutions and outline the dire consequences of not settling", but this power is far more direct and draconian when the mediator can impose a decision. ${ }^{91}$ The competence of the med-arbiter becomes fundamental to the effectiveness of the process, ${ }^{92}$ yet different skills are required for the two processes, ${ }^{93}$ and for sexual harassment complaints it is also imperative that the medarbiter has a thorough understanding of the specific characteristics of sexual harassment cases. Some commentators are not overly concerned with the dangers of co-erced agreements: $^{94}$

Med-arb settlements albeit reached reluctantly are nevertheless agreements by the parties to the dispute. Like any forced feeding mediation-arbitration sometimes leaves the parties with sore spots on their throats.

Yet in sexual harassment cases where the behaviour has been admitted, such an attitude is wholly inappropriate as the law specifically states that the behaviour is illegal and inappropriate. If the behaviour has not been admitted, a fact-finding is necessary. Sexual harassment complaints are not situations where 'banging the parties heads together' to produce an outcome should even be considered.

89 See D White Exploring the Morality of Med-Arb: An Analysis of the Appropriateness of Section 88(2) of the Employment Contracts Act 1991 Unpublished LLM Research Paper, Victoria University of Wellington 1996.

90 BC Bartel "Med-arb as a Distinct Method of Dispute Resolution: History, Analysis, Potential" (1991) 27 Williamette LR 661, 679.

41 Above n 89, 17.

92 S Kagel "Combining Mediation and Arbitration" (1973) 96 Monthly Labor Review 62.

93 Above $\mathbf{n} 90,689$.

94 Above $\mathbf{n} 92,265$. See also above $\mathbf{n} 90,690$. 


\section{Compromise, Perceptions and Common Interests}

The basic ethos of mediation is that a consensus is reached by focusing on the interests and perceptions of the parties and finding common ground on which to build a mutually beneficial solution. This is not appropriate for the resolution of sexual harassment claims.

In cases where the sexual harassment complaint is false and the alleged behaviour did not take place, compromise and settlement should not take place; rather, a finding of fact is necessary. In cases where there has been sexual harassment, the parties are quite likely to have different perceptions of the circumstances and different accounts of the facts. West has written about the way that many gendered harms are viewed quite differently by the man and woman involved. The term "sexual harassment" in itself "capture[s] these different subjective experiences of shared social realities: for the man, the office pass was sex (and pleasurable), for the woman, it was harassment (and painful)." ${ }^{95}$ However, these two versions are not equally valid in these circumstances. Sexual harassment involves behaviour which has been made unlawful under the Human Rights Act 1993 and the Employment Contracts Act 1991. As the Court held in $Z v$ A, sexual harassment is ${ }^{96}$

... entirely devoid of any redeeming features. It follows that its occurrence can never be met with matters of justification, excuse or mitigation. It is an attack on the basic human right that all persons must be supposed to have to pursue their economic freedom in conditions of freedom and dignity. Its victims are almost invariably women. It is insidious and deceptive in character.

As the standard of behaviour has been set by the legislature, there should be no room for compromise in terms of the behaviour itself and whether it constituted sexual harassment or not. There are a range of cases which help to define what kind of behaviour constitutes sexual harassment, and the test for the hostile environment type of harassment is, in both the HRA and the ECA, subjective to the woman as to whether the behaviour of a sexual nature was "unwelcome or offensive".97

To attempt to mediate on whether or not the behaviour constituted sexual harassment and how serious a breach of the Act it was, defeats the point of the subjective standard and invites not co-operation but dissent and negation of the woman's experiences and feelings in the most adversarial of ways. The only option that the harasser has is to blame the victim,

RL West "The Difference in Women's Hedonic Lives: A Phenomenological Critique of Feminist Legal Theory " in M Fineman and N Thomadsen (eds) At the Boundaries of Law (Routledge, New York, 1991) 115, 125.

$\mathrm{Z} v A$ above $\mathrm{n} 11,472$.

Section 62 of the Human Rights Act 1993 and section 29 of the Employment Contracts Act 1991. 
deny the behaviour, deny it was sexual and/or deny the feelings of the complainant. ${ }^{98}$ This may be attempted by bringing the woman's behaviour into dispute. If this is the case, mediation as a forum will often be more dangerous for such an enquiry than the Court system which provides some protections to the complainant in terms of evidential rules.

Under the Human Rights Act 1993 the compulsory conciliation after the Complaints Division investigation has found that the complaint has substance, is in theory focussed not on the behaviour itself, but rather on the remedies to be offered to the complainant. However, an obvious negotiation tactic is for the party against whom the complaint has been upheld, to challenge the opinion of the Complaints Division. ${ }^{99}$ Such a response is not at all surprising as to start a conciliation with the facts established and supposedly not open to review is likely to put the harasser on the defensive and lead to adversarial non-cooperative behaviour. Without challenging the opinion of the Complaints Division, the harasser may feel that he has no bargaining power at all.

I am not suggesting in this discussion that the perceptions and emotions of the harasser are non-existent or are totally irrelevant. However, the place to deal with them is not in a conciliation or mediation, but through counselling and an education programme. This was recognised by the Employment Court in $\mathrm{Z} v \mathrm{~A}^{:{ }^{100}}$

When the Tribunal finds that an employee has been sexually harassed in the employee's employment and the person or persons responsible is known or identifiable, the Tribunal should ordinarily recommend to the employer that it arrange rehabilitative counselling for that person or persons.

The complainant too may need separate counselling to deal with the effects of sexual harassment, but this must be optional. A woman who has been sexually harassed should not also be placed in the position of having the responsibility of educating the harasser as to what constitutes sexual harassment and the detrimental effects of the behaviour.

In sexual harassment cases then both parties' perceptions and views of the facts are not equally valid. There are also difficulties with the general view that "[t]he legal rights of the

98 The likelihood of this occurring is shown by the HRC comment that in sexual harassment litigation "respondents characteristically find it difficult to accept adverse findings." Above n 24, 33.

9y I have seen exactly this tactic used in a HRC mediation.

101) Above $n$ 11, 496. This power is available under section 40(1)(d) of the ECA 1991, but in fact it is infrequently used. See C Morris "An Investigation into Gender Bias in the Employment Institutions" (1996) $26 \mathrm{NZ}$ Jnl Ind Rel 67,79. Note also that the employer does have a duty under section 36(2) of the ECA 1991 to take whatever steps are practicable to prevent any repetition of sexual harassment by any employee/client/customer. 
parties are not central to the discussion which takes place in mediation."101 Obviously this depends on the type of mediation used in the particular context, and of course in practice the parties in a mediation are "bargaining in the shadow of the law". ${ }^{102}$ In other words the likely outcome of any litigation and the parties' legal rights are likely to have some impact on the outcome of any mediation.

To my mind though, this is not enough. In sexual harassment cases both the parties' legal rights should be central to any discussion. This is also imperative to change society's views on sexual harassment through the public articulation of norms. Sexual harassment is a relatively new concept, only accepted in New Zealand law in $1985 .{ }^{103}$ It has not yet gained widespread understanding and legitimacy in New Zealand society. One illustration of this is the likely vast under-reporting and non-intervention in sexual harassment cases. ${ }^{104}$ For example the Human Rights Commission received several thousand enquiries concerning sexual harassment between 1994 and 1996, yet can only open formal complaints in approximately $10 \%$ of cases. ${ }^{105}$ Legal rights are the language that the legal system and our society in general is most familiar with and accepts most readily. For the disempowered in society they have provided an impetus for change. ${ }^{106}$ To increase public awareness and the legitimacy of sexual harassment, it is essential that the law in this area, which has been described as "the best in the world", ${ }^{107}$ is not pushed to the fringes when dealing with complaints.

See for example above $n$ 1, 27.

See above $n 53$.

The Equal Opportunities Tribunal recognised sexual harassment as a form of sex discrimination under the Human Rights Commission Act 1977 in Hv E [1985] 5 NZAR 333.

F Joychild "A Critique of the Law of Sexual Harassment in Aotearoa/New Zealand" (Women's Law Conference Papers 1993, New Zealand Suffrage Centennial )43, 56.

For the year ending June 1994, 550 sexual harassment enquiries were made, 91 of which were investigated; in 1995631 enquiries led to 40 investigated complaints; in 1996 there were 758 enquiries of which 55 complaints were investigated. Above $n 35$.

See P Williams "Alchemical Notes: Reconstructing Ideals from Deconstructed Rights" (1987) Harv Civil Liberties LR 401.

W Davis "A Feminist Perspective on Sexual Harassment in Employment Law in New Zealand" (Monograph No 3, NZ Institute of Industrial Relations Research, Wellington, 1994) 28. Note that while Davis regards the law itself highly, she is critical of the implementation of the law. 


\section{Privatisation and Confidentially}

One benefit of mediation/conciliation is often seen to be its confidential and private nature and this may be part of the reason that the processes are used in sexual harassment cases. $^{108}$

Perhaps because sex had been associated with the family sphere and because sexual

harassment is characterised as a sexual activity, harassment proceedings have often been

dealt with in private with the minimum of public disclosure.

Privacy and confidentiality can be detrimental to the justice system as a whole, especially in sexual harassment cases. The private nature of conciliation/mediation reduces the accountability of the institutionalised systems. Thus for example, the reporting of complaints taken under the HRA are largely focused on the number of settled complaints and the time within which complaints were dealt with. One or two cases may be written up briefly in the annual report. ${ }^{109}$ Detail is not given as to how exactly HRC conciliation, or mediation under the ECA works, what settlements are reached, or what behaviour is constituting sexual harassment. Yet this detail is essential to educate the public and to set public norms about what is legitimate behaviour and what is not. ${ }^{110}$ Women need to know when behaviour they are experiencing is sexual harassment and what will happen if they choose to complain about such behaviour. Men need to be educated about the boundaries of behaviour in the workplace and in other (public) settings. ${ }^{111}$ It is recognised as central to our court system that courts are open to the public and that judgments are published thus setting or articulating public norms and educating the public about legal standards. ${ }^{112}$

V Grainer "Refining the Regulation of Sexual Harassment" in E MacDonald and G Austin (eds) Claiming the Law (1993) 23 VUWLR 127, 133.

For example see above $n$ 35, 34 and above $n$ 24, 26-28.

See JA Scutt "The Privatisation of Justice: Power Differentials, Inequality, and the Palliative of Counselling and Mediation" (1988) 11 Women's Studies Int Forum 503, 507-511.

Under the HRA only 'public' areas are covered by the Act, eg educational establishments, access to goods and services etc. So for example the Complaints Review Tribunal struck out the proceedings in Proceedings Commissioner $v$ Mundy CRT 7/96 on the basis that as the defendant shared premises with the complainants the residential accommodation exception in s 54 HRA 1993 applied.

112 See C Baylis "Justice Done and Justice Seen to be Done: The Public Administration of Justice" (1991) 21 VUWLR 177. 
Privacy and confidentiality can also be detrimental on an individual level. They are not necessarily neutral concepts which benefit both parties. There are real dangers involved in processes which maintain a shield of secrecy about sexual harassment: ${ }^{113}$

Sexual abuse mutes victims socially through the violation itself. Often the abuser enforces secrecy and silence; secrecy and silence may be part of what is so sexy about sexual abuse.

When the state also forecloses a validated space for denouncing and rectifying the victimizaiton, it seals this secrecy and reinforces this silence.

It is usual for mediated settlements to involve confidentiality clauses, with the result that women are silenced about their experiences, that other women do not learn of this man's behaviour or do not realise that what he has been doing to them has happened to other women already.

As against this there is a need for confidentiality for the complainant in sexual harassment cases. Sexual harassment is unfortunately not always understood, and a woman who makes a complaint can still be subject to prejudice as a result. As sexual harassment often occurs in the workplace, this can affect a woman's economic livelihood. On the other hand, it is important that sexual harassers are identified. At present, sexual harassment "perpetrators have been afforded the same sacrosanct privacy that has surrounded legitimate sexual activity." ${ }^{114}$ Yet sexual harassment does not tend to be one-off behaviour; often sexual harassers will have harassed other women and there is the danger that they will continue to harass. ${ }^{115}$ Again in $Z v A$ the Court recognised these dangers: ${ }^{116}$

... the world is probably entitled to know who the sexual harassers are, and for whom they work, and where, because that will enable their superiors, and indeed compel them, to take steps to ensure that other employees will not be subjected to the conduct complained of and may also lead to the harasser changing his or her ways.

CA MacKinnon Feminism Unmodified (Harvard Univ Press, Cambridge, Mass, 1987) 104.

Above n 108, 133.

This is reflected in the fact that the HRC can order counselling to try to effect change in the harasser's behaviour. Above $n$ 104, 61 and 60 .

Above n 11, 476. See also above n 108, 134. 
Thus there are two sets of imperatives taking place in the regulation of sexual harassment: first, the set established by the statutes, and in the Employment Court in $\mathrm{ZvA},{ }^{117}$ and secondly, an often contradictory set maintained by the nature of the informal private dispute resolution, where in fact most sexual harassment complaints are resolved. The gap between these two approaches needs to be narrowed, through an understanding of the dangers of informal dispute resolution for sexual harassment complaints.

\section{On-going relationships, multiple parties and multi-dimensional issues}

Mediation proponents also suggest that there are a number of types of disputes which mediation is often more capable of dealing with effectively than the adversarial system. Fuller referred to polycentric issues, where a range of different issues are raised by the case, all of which interconnect and have a bearing on each other. ${ }^{118}$ For example, in the family law area, custody, access, maintenance and even the division of property are likely to interconnect. However, sexual harassment cases do not usually raise a wide range of issues, the focus is generally on whether the alleged behaviour occurred, and whether the legal standard was met, followed by the decision as to the appropriate remedy or outcome.

Similarly mediation is often seen as better able to deal with issues which involve multiple parties with different interests in a dispute. ${ }^{119}$ While sexual harassment cases can sometimes involve a number of complainants or harassers, within each group there is not likely to be widely divergent interests.

Finally mediation is often favoured where there is an ongoing relationship between the parties. ${ }^{120}$ This is part of the reason that it is legislatively prescribed in the residential tenancies, employment and family law areas. However, in sexual harassment disputes the woman has quite commonly left her job or the setting of the sexual harassment prior to her making a complaint or prior to it being dealt with, so there is no on-going relationship. Where a harasser and complainant do still work together or have other on-going contact, the notion that mediation may lead to a better future working relationship is not necessarily

117 Above $\mathrm{n}$ 11. I point to this particular case as the Court and Tribunal have not always lived up to the imperatives set by the case. For example the recommendatory powers on education programmes are not frequently used Morris above $\mathrm{n} 88,13$ and the recent shocking decision of Lenart $v$ Massey University Unreported, March 1997, Employment Court, Wellington Registry WEC 15/97 shows a real lack of understanding on the part of the Judge of the nature of sexual harassment.

118 LL Fuller "Mediation - Its Forms and Functions" (1971) 44 S Cal L Rev 305.

119 See C Menkel-Meadow above n 10, 10, for discussion on adjudication's inability to deal with such disputes.

See BH Herrnstein "Women and Mediation: A Chance to Speak and Be Heard" (1996) 13 Mediation Quarterly 229, 234. 
true. For the woman to be told that she must conciliate and negotiate with the harasser may leave her feeling much more powerless than if a decision was made by a third party that her complaint had substance and that the harasser must now comply with certain conditions and pay a sum of compensation. Similarly the fairly common outcome that no liability is admitted, although a monetary settlement is reached ${ }^{121}$ is unlikely to aid a healthy future relationship.

To point to the specific characteristics of disputes to which mediation may be particularly suited is thus not persuasive when matched with the nature of most sexual harassment cases.

\section{B Better Outcomes:}

Mediation is often purported to produce better outcomes compared to those of the adversarial system. Partly this claim is related to the process claims analysed above, in that the ability of mediation to examine both the parties' perceptions and interests rather than merely the legal rights in a case, allows for a solution which both parties might find more relevant and beneficial to them. Similarly the fact that mediation as a process may be better able to cope with multi-issue, multi-party disputes again means that the solution in such cases may produce a greater level of satisfaction to the parties and may be seen to be more in line with the public interest.

However, to some degree this claim that mediation can produce a better outcome is also separate from, and additional to, the process claims. Mediation, in theory at least, produces creative outcomes which if the process has worked effectively, are advantageous to both parties. The outcome then is not usually a binary win/lose situation as with litigation, but rather, according to the rhetoric at least, a win/win outcome. This is achieved by focusing on both parties interests, and by "each party giv[ing] up what he values less, in return for what he values more. ${ }^{122}$ In reality of course this is not always possible, but still mediation does not fall back on the win/lose outcome. In these situations the aim is to find a settlement which may involve compromise, but it is compromise which comes from both sides, ideally more willingly now that the other party's perceptions and interests have been understood.

All this theory may well break down in practice depending on the mediator's skills, the degree to which the parties wish to settle the dispute and the extent to which they are willing to participate in multi-dimensional problem solving rather than an adversarial

121 This was the outcome in the case described in the text accompanying footnote 65 where there was no admission of liability although "a written apology, a factual work reference and $\$ 9,000$ compensation for pain and humiliation were forthcoming." Above n 24, 27.

122 L Fuller "Collective Bargaining and the Arbitrator" in S Goldberg, E Green \& F Sander Dispute Resolution (Little Brown, Boston, 1985) 248. 
fight. ${ }^{123}$ The latter may also depend on the involvement of legal counsel in the process and their ability to shift paradigm from the adversarial focus on winning at almost any $\operatorname{cost}^{124}$ to that of a trust culture where co-operation is necessary to achieve mutually beneficial creative outcomes.

This possible disparity between the theory and practice is intensified under both the HRA and the ECA processes, due to the particular statutory models which have been established.

In terms of sexual harassment complaints there is again an even more fundamental question which must be addressed, as to the degree to which co-operative mutually beneficial compromise solutions are actually appropriate. Fiss identifies general problems with mediation settlements which are particularly pertinent to sexual harassment complaints. He believes that the parties are effectively choosing peace over justice, the latter being achieved, he suggests, through adjudication. ${ }^{125}$ His view is that when parties settle, this means "to accept less than some ideal"126 and that "society gets less than what appears, and for a price it does not know it is paying. Parties might settle while leaving justice undone. ${ }^{127}$ Whereas to him, the purpose of adjudication is: ${ }^{128}$

... not to maximize the ends of private parties, nor simply to secure peace, but to explicate and give force to the values embodied in authoritative texts such as the Constitution and statutes: to interpret these values and to bring reality into accord with them.

While I do not think that the adversarial system is the best forum for sexual harassment cases, I do agree that conciliation/mediation has too much of a focus on achieving peace between the parties rather than broader societal aims and justice for the harassed woman.

Sexual harassment is behaviour which is harmful and debilitating to those who are subjected to it. It can include criminal behaviour such as sexual violation and assault and some cases of this nature are reported to the Human Rights Commission rather than to the Police. The effects of sexual harassment are ongoing and severe. People leave their jobs, their career prospects are damaged, there is stigma involved and psychological consequences. A woman's motivation for her work is likely to be affected by workplace System" (1995) 10 Wis Women's LJ 225, 261.

See above n 123.

O Fiss "Against Settlement" (1984) 93 Yale LJ 1073, 1085-7.

Above n 125, 1086

Above n 125, 1085

Above n 125, 1085 
harassment, as well as her personal and work relationships with others. Even moving to a new job may be difficult if the harasser is someone who should or would normally give a reference. The legislature has recognised the seriousness of sexual harassment in the form of statutory prohibitions, and the Courts have at times picked up on this, for example in $Z v A$, where Chief Judge Goddard agreed with US Courts that "[s]exual harassment poisons the workplace" and "is wholly unacceptable." 129

For a woman to make a formal complaint of sexual harassment is an incredibly difficult and traumatic decision. The majority of sexual harassment goes unreported. To be expected to act co-operatively towards any mutually beneficial outcome is not realistic, feasible or desirable. The message given to the complainant when asked to conciliate, even on a remedy, in sexual harassment cases is that the behaviour is not unequivocally unacceptable. In conciliating/mediating the values in the statutes are not being interpreted nor are they "bring[ing] reality into accord with them." ${ }^{130}$ How seriously is sexual harassment being treated if the complainant is told - yes we believe this happened but now we want you to negotiate a settlement with the person who sexually harassed you? Mediation/conciliation will almost always involve some compromise on the complainant's part as well as the harasser's, otherwise it is not really a settlement. ${ }^{131}$ When the complaint has been found to have substance under the HRA, why should the complainant be compromising, why are her rights not being directly enforced?: ${ }^{132}$

As between black and white, gray may sometimes seem an acceptable compromise, but there are circumstances in which it is essential to work hard toward keeping things black and white.

One of the fundamental tenets of our justice system is the degree to which the system is based on precedent and consistency, so that similar wrongs are treated similarly by the Courts. The Courts do, of course, examine the individual facts of a case, and the claim of a scientific objectivity is overrated, yet some measure of overall consistency is achieved. On the other hand in conciliation or mediation the results may be widely variant, depending on the skills and manipulation of the advocates or parties, the mediator's input and the degree to which one or both parties wish to avoid the next step in the process. Some women may also be more willing to compromise to get the conciliation over with, hoping perhaps that the HRC finding in itself will prevent the harasser from repeating the behaviour with another woman.

$\mathrm{Z} v A$ above $\mathrm{n} 11,472$. Although there are other decisions which are highly problematic for example see above $n 117$.

Above $\mathrm{n} 125$.

See above n 108, 135; above n 18, A/ 1668 para 80.2.

Above n 118, 328. 
What makes this push for peace between the parties all the more problematic is the factor Grillo identifies, that "[i]f one party appreciates co-operation more than the other, the parties might compromise unequally." ${ }^{133}$ Yet some feminist proponents of mediation view it as a better alternative for women because it is a discourse which values co-operation which is in keeping with the 'different voice' identified by Gilligan as more often belonging to women. ${ }^{134}$ The danger then is that women will compromise more readily, which produces problematic outcomes and the disempowerment of women. The willingness to compromise may occur because it is more in women's nature to do so, or because this is another characteristic which women have learnt in a patriarchal society having been valued for their non-competitive, co-operative outlooks. ${ }^{135}$ Menkel-Meadow, one such feminist proponent of mediation agrees to some extent with Fiss, arguing that settlement processes may be inappropriate: ${ }^{136}$

... when the issue has an impact on the public; or when, even in a 'private' dispute, there is a need for an authoritative third-party ruling (ie, when one party seeks vindication or when the force of a court order is necessary to bring about compliance.)

Consequently her suggestion is that we have to become more sophisticated in choosing appropriate cases for any type of dispute resolution process. ${ }^{137}$

As discussed above, sexual harassment cases should be having an impact on the public, and certainly they are cases where an authoritative ruling is essential. All the more so, because of the fairly common psychological reaction of women who have been harassed which is to wonder if they are at fault. This may again lead to more of an inclination on the part of the woman to settle a case to their disadvantage or at least not to their best advantage. ${ }^{138}$ Again the source of such "feminine guilt"139 is irrelevant, although I believe it

T Grillo above $n$ 31, 1608.

See above $n 31$.

See C MacKinnon in Du Bois et al above n 31, 73-5.

C Menkel-Meadow "For and Against Settlement: Uses and Abuses of the Mandatory Settlement Conference" (1985) 33 UCLA LR 485,500.

See Menkel-Meadow above $\mathrm{n} 10$.

See for example above n 1, 46-7; and PA Gwartney-Gibbs and DH Lach "Workplace Dispute Resolution and Gender Inequality" (1991) 7 Negotiation Jnl 187,191.

Above n 1, 46. 
stems directly from gender oppression in society and from the way the legal system approaches the types of illegal behaviour where women are usually the victims. ${ }^{140}$

Finally under the HRA process particularly, due to its focus on the remedy, but also under ECA mediation, there is a responsibility shift from the state to the individual woman as to the outcome for the harasser. Under the criminal law, there has been a move towards the use of victim impact reports, but these do not encompass suggestions as to sentencing, and it is still ultimately the state that determines the punishment for the offender. By shifting responsibility to a mediated settlement the harassed woman is directly implicated in any outcome and has to bear part of the responsibility for that outcome, yet the outcome has arisen because of the harasser's actions, because of his breach of a legal standard of behaviour. The danger with the outcome being negotiated by the parties is that the woman either may worry after the event about whether she/her lawyer pushed too hard, or she may not bargain for what she feels is just due to a risk of being seen as greedy or as being too harsh on the harasser. It is not uncommon in sexual harassment cases for women to focus not on themselves, but only on the harasser stopping the behaviour, both in relation to them and to others. This attitude may be intrinsically tied up with the power relationship involved. $^{141}$

At the most basic level, the aim of mediating these types of disputes can be questioned. The legal standard of behaviour is set to prohibit sexual harassment in the workplace and various other settings. The aim of any dispute involving a complaint of sexual harassment must be to examine the facts and if the harassment occurred, to stop that person doing it again and to deter others from doing it at all. Mediation is unlikely to achieve either of these aims. Abel does not think mediation is capable of changing participant's behaviour ${ }^{142}$ and due to the confidentiality involved it may be difficult to check whether this has occurred anyway. ${ }^{143}$ Secondly, as has been discussed above, due to the private nature of mediation and the lack of reporting of the outcomes there are few public standards being set which will deter others.

It is interesting to consider the possible reasons why the legislature continues to expect women who have been harassed to conciliate/mediate with their harasser even though this

140 For example by discussing the degree to which a woman's clothes or behaviour was "asking for" rape etc. See also above $n$ 95, 116-119.

This and the responsibility some women feel for the sexual harassment itself may be similar to the situation in some domestic abuse cases. See above $n$ 1, 47.

142 Above n 44, 278.

143 While the HRC may be able to detect a pattern of behaviour, this relies on women reporting the harassment, reporting it formally outside the institution/workplace setting, and in doing so choosing the HRA process not the ECA. 
seems to be highly inappropriate. It may be that the legislature did not understand the seriousness of the behaviour which can be and is complained of to the HRC, or it may not have understood the debilitating and harmful effects of all types of sexual harassment on the women who are subjected to it. This failure to understand the significance of the effects of the behaviour may be because these effects are often emotional, mental effects rather than tangible physical harm. However the law deals adequately with the intangible harm of loss of reputation due to defamation, which points more strongly towards the feminist thesis that the law fails to treat seriously gendered harms such as sexual harassment. This may occur because of the systemic subordination of women in society or because these harms are different to those generally experienced by men, and are therefore not understood and are trivialised by the predominantly male legal culture. ${ }^{144}$ Whatever the reason the result is the same.

Partly the presence of conciliation in the sexual harassment process under the HRA may be a lack of confidence in the due process protections of the investigatory approach undertaken by the Commission. Conciliation, by giving some input to the harasser, may be seen as tempering this apparent lack. Such a lack of confidence does not necessarily mean that the process is less likely to arrive at the "truth" or at a real representation of the facts of the case. I believe that the lack of confidence comes more from the nature of the assumptions upon which our adversarial system is based. Our justice system holds that the truth is more likely to become apparent through a public contest, between partisan representatives of the different sides of the argument, with a 'neutral' decision-maker effectively umpiring the contest. However, these assumptions are not universal, the inquisitorial system, is based on quite different and indeed often contradictory assumptions. ${ }^{145}$

Evidence in the two procedures [that is the adversarial procedure and the inquisitorial procedure] is based on different psychological assumptions. In the accusatorial procedure it is assumed that a witness is unlikely to tell the truth unless he testifies in open court, so that what he says can be challenged by the party against whom he is testifying. In the inquisitorial procedure it is assumed that a witness will be inhibited by the prospect of challenge and that he is more likely to tell the truth in private to a judge who questions him from a neutral standpoint.

It is an arrogance of our adversarial system that we believe we have the only/best way of finding truth. I would again advocate that we need to become more flexible about the type

See above $\mathrm{n} 95$. 
of dispute resolution process that is used depending on the characteristics of the type of dispute in question.

\section{DEVELOPING APPROPRIATE DISPUTE RESOLUTION FOR SEXUAL HARASSMENT COMPLAINTS - TENTATIVE THOUGHTS}

I do not view the adversarial system as being the only method of finding 'truth', and nor do I view my argument that mediation/conciliation is inappropriate for sexual harassment complaints as leading inevitably back to the adversarial system. I also reject an essentialist view that all sexual harassment complainants have the same interests and needs, thus it is imperative for women to have choices in terms of resolving these complaints. I also maintain that it is essential for any person with a role in the system and who is dealing with sexual harassment complaints to be trained in gender issues, and more particularly in the aetiology of sexual harassment. Such training needs to be on-going, and accountability mechanisms need to be established to ensure that these people are not reinforcing the systemic discrimination of women by their attitudes or treatment in the process in which they are involved.

To ensure choice then perhaps the Employment Tribunal should continue to use mediation, providing training is undertaken. More research and analysis is needed into med-arb and the specific model established under the ECA. While the HRC conciliators may well have more thorough training and thus understanding of sexual harassment, I believe that we should change the process under the HRA. At the least conciliation should not be compulsory. To my mind, however, it is time we tried a different approach, by placing more faith in the investigatory process undertaken by the Complaints division in the HRC. ${ }^{146}$ This approach has procedural checks to ensure that natural justice requirements are complied with, so for example, both parties see written copies of all the evidence given by the other party and witnesses. The legislature is already investing significant resources into this process. ${ }^{147}$ It should now be given full backing, by making the result of the investigation a finding rather than an opinion. After such an investigation, I would suggest that a panel including at least one HR Commissioner determines the appropriate outcome in the case, thus shifting the responsibility from the complainant and removing the harasser from having decision-making power in this regard. Similarly to the inquisitorial system, the panel could

Menkel-Meadow suggests an "inquisitorial-bureaucratic investigation" process as one option of dispute resolution which should be considered when determining the type of process that should be used. C Menkel-Meadow above $\mathrm{n} 10,12$. Such a process is used by the Ombudsman's Office in determining claims under both the Ombudsman Act 1975 and the Official Information Act 1982. Although the Ombudsman's powers are only recommendatory, a recommendation under the latter gives rise to an enforceable duty after 21 days.

147 Although not enough resources to deal with all complaints or to deal with those that are investigated in a timely manner. 
include the investigating officer and could review the finding of that officer. The panel could also hear from the complainant and the harasser in terms of the appropriate remedy/outcome of the case. These outcomes should be published ensuring only that the privacy of the complainant is protected. ${ }^{148}$ The investigation finding and the outcome could be subject to judicial review, or appeal to the Complaints Review Tribunal.

\section{CONCLUSION}

In New Zealand we are too readily legislating conciliation/mediation into statutory dispute resolution processes without enough thought about the appropriateness of the type of dispute for that species of dispute resolution process. There is also a real danger with blanket decisions that all disputes of one particular variety go to mediation. People should have a choice and certainly those running the processes should be able to divert inappropriate cases, rather than having to conciliate.

To my mind, sexual harassment in particular is not appropriate for conciliation/mediation. Women who have been subject to the trauma and debilitating effects of this behaviour should have the option of a dispute resolution process which is sensitive to their needs, does not ask them to compromise with their harasser or to validate his perceptions of the events, and which can set unequivocal public standards that sexual harassment is not acceptable behaviour. It is only in this way that other women will be protected from harassment and from having to go through the further trauma that any complaint process necessarily involves. 